\title{
IMWG Minimal Response
}

National Cancer Institute

\section{Source}

National Cancer Institute. IMWG Minimal Response. NCI Thesaurus. Code C159809.

At least 25 percent but less than 50 percent reduction of serum M-protein and reduction in 24-hour urine M-protein by 50-89 percent. In addition to the above listed criteria, if present at baseline, at least a 50 percent reduction in the size (sum of products of diameters) of soft tissue plasmacytomas is also required. 